\title{
Adoption of computers in Dutch Museums: interpreting the new tool
}

\section{Background}

The Internet has become a starting point for communicating with the world and because of this media theory has increasingly taken the Internet as key subject of research. Numerous studies have looked at the role of social media platforms in all areas of society including politics, economics, communication, identity building, memory and feminism to name a few. ${ }^{\mathrm{I}}$ Some authors have specifically looked at social media as an environment where heritage content from galleries, libraries, archives and museums (the so-called GLAMs) is exchanged. ${ }^{2}$ One example of heritage content positioned in social media is the photograph collection of the Tropenmuseum, an ethnographic museum in Amsterdam. One image of a negative depicting a man from Indonesia entitled Lontarpalm has been published as part of a Wikipedia article (see illustration I) and at the museum's collection (illustration 2). Since 2008, the museum has delivered over Io०,००० photographs and media files from the Marron, Suriname, Indonesia and Africa collections of which, by 2012, close to 5,000 were used in various Wikipedia articles receiving close to ten million views per month. ${ }^{3}$

Resources have been allocated to encourage access to heritage content, either in the form of subsidies to digitize and to distribute collection information on social media, or more recently as staff to write articles using heritage content from the GLAMS. New positions, called Wikipedian in Residence, are found in organizations such as the British Museum, the Museum Picasso, the Archives of American Art, the Royal Library of Denmark or the National Library of Israel to name a few. ${ }^{4}$ In the Netherlands, the first Wikipedian in Residence was hired by the National Library and the National Archives in a joint project to position collections in Wikimedia, to support staff's understanding of the collection publication process, to strengthen the relationship with the public and to increase awareness of the potentials brought by such online publication of collections. ${ }^{5}$ Allocating resources to publish heritage collections online appears to yield an exponential access to collections. Online access to information is expected to grow considering that, in 2005 , only II\% of the Dutch population had a mobile phone with Internet access and by 2013 the percentage had risen to $73 \%{ }^{6}$

What is the impact of heritage content distribution on social media? The Wikipedia Foundation is in the process of developing a series of tools to track page views of the Wikipedia articles containing GLAMs content (see Figure I). 


\section{Histoire de la culture des plantes sucrières}

\author{
L'histoire de la culture des \\ plantes sucrières couvre \\ une période allant de la haute \\ Antiquité à nos jours. \\ Mais c'est surtout à partir du \\ milieu du XVII ${ }^{e}$ siècle, avec le \\ développement du \\ mercantilisme et du \\ colonialisme, que commence \\ la période dite industrielle \\ avec la Caraïbe qui devient la \\ principale région mondiale \\ pour la production du sucre \\ obtenu à partir de la canne. \\ Cette période connaît une \\ expansion à marche forcée \\ au siècle suivant, marquée \\ par le commerce triangulaire \\ vers les îles françaises et \\ anglaises. Elle n'a cédé cette \\ place qu'à la fin du XIX ${ }^{\mathrm{e}}$ siècle \\ avec l'abolition de l'esclavage \\ et le développement de la \\ culture de la betterave \\ sucrière en Europe.
}

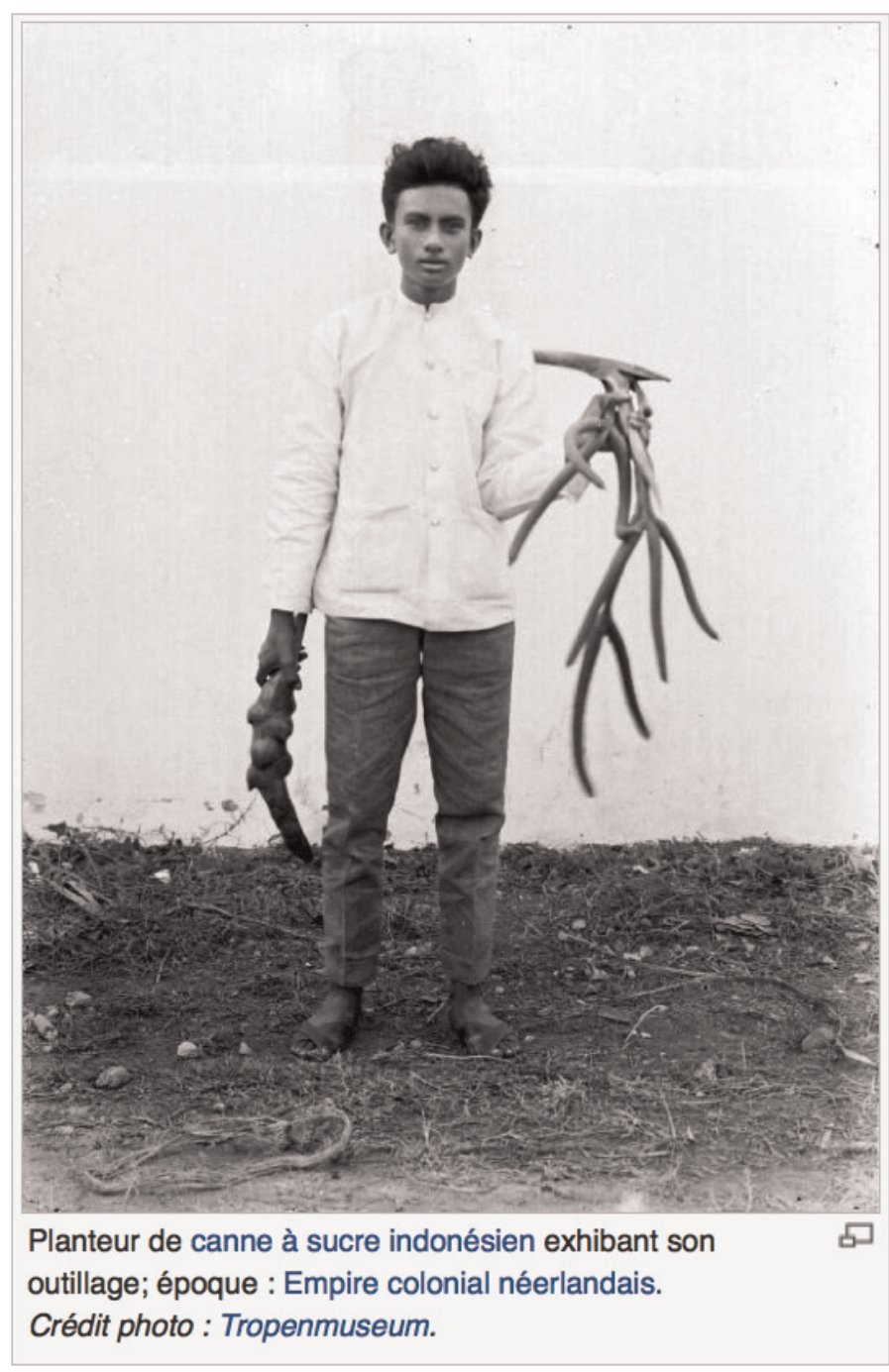

$\mathrm{Au} \mathrm{Xx} \mathrm{e}^{\mathrm{e}}$ siècle, Cuba reste longtemps premier exportateur mondial de sucre.

Ill. I. Screenshot of a negative from the Tropenmuseum made available in Wikimedia and used in a Wikipedia article. Source: http://fr.wikipedia.org/wiki/Histoire_de_la_culture_des_plantes_sucrières.

The content of the Tropenmuseum available in Wikipedia, through the Wikimedia archive, has received more than 370 billion page views in the last 50 months. From data available from the BagLAma tool (see Figure I), available from the Wikimedia Foundation, a breakdown reveals that there are 582 pages in the French language Wikipedia containing images from the Tropenmuseum which have received more than a half million views in September 2014.

The large increase in online attention after repositioning objects within various contexts is no surprise. After all, contextualization has long been perceived as key in the understanding of collections. Museum objects have a polysemic nature in that "they possess the potential to be interpreted in a variety of ways... An object's meaning, or indeed its classification, is not selfevident or singular, but is imposed on it". 7 For this reason, museum objects can be linked to information along a scale of raw (basic facts: size, name, origin, materials), refined (keywords, use) 


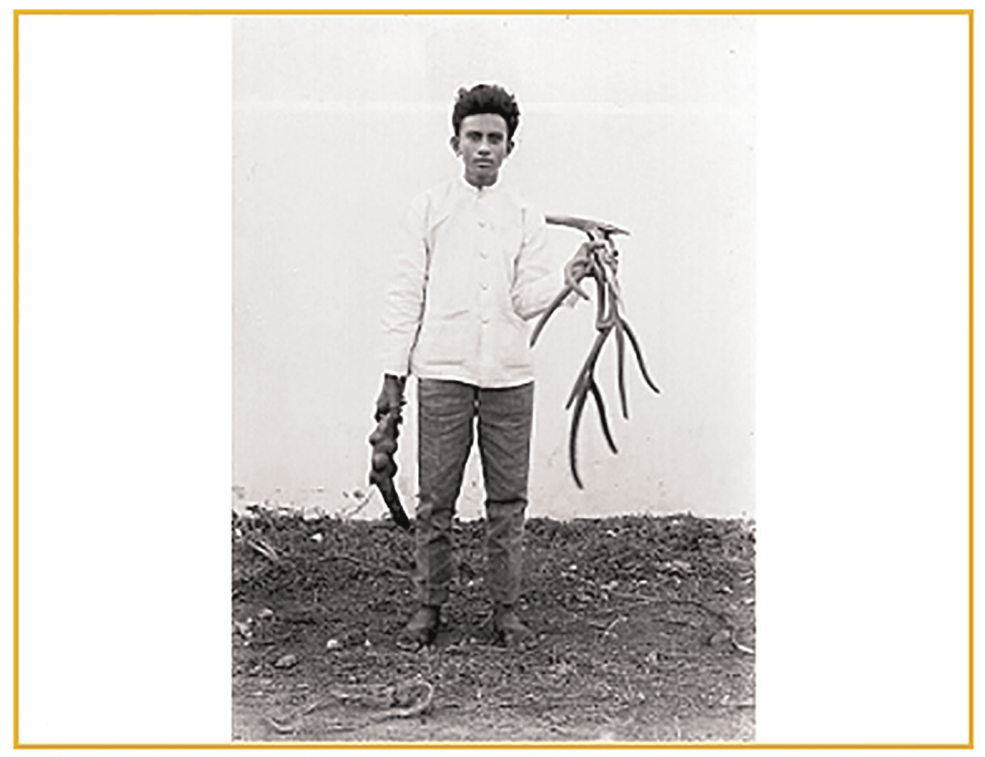

\section{Object Trefwoorden}

\section{Herkomst}

Indonesisch, Indonesië

Datering

[N.B.]

\section{Afmetingen}

$11,9 \times 16,3 \mathrm{~cm}$ (4 11/16 6 7/16in.)

\section{Inventarisnummer}

10011771

Ill. 2. Screenshot of a negative from the Tropenmuseum made available in Wikimedia and used in a Wikipedia article. Source: http://collectie.tropenmuseum.nl/Default.aspx?ccid=229472.

and mediated information (narrative or interpretative data: significance, meaning, role in the collection). ${ }^{8}$

So, why did museums come to use digital media to communicate collection information with their public? And what was the organizational process to adopt the digital technology, starting from the use of the first computers and continuing with the publication of collections on the web, that has allowed user engagement as seen with Wikipedia?

The aim of this paper is to discuss the decisions made by museums in their process to adopt digital media, interpreted as technology meant to solve a problem, culminating in the current interactive publication of collections as found on Wikipedia. This paper describes a couple of examples showing different approaches of providing access to collections across time. Museums can differ and can change in their interpretation of digital technology usage and, most importantly, in the potential to communicate with users. A historical review highlights the 


\section{Wikipedia article traffic statistics}

Histoire_de_la_culture_des_plantes_sucrières has been viewed 1005 times in the last 90 days.

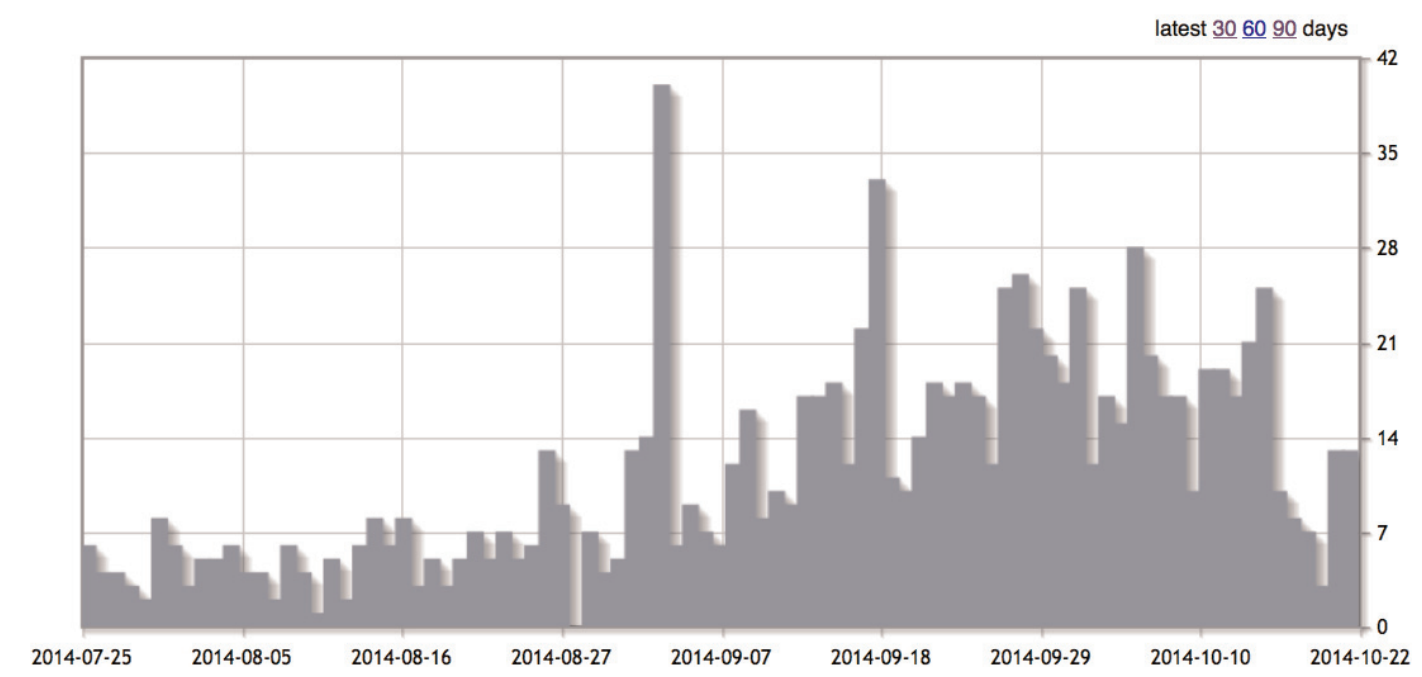

Figure I. Wikipedia article traffic of page using the Baglama tool.

Source: http://stats.grok.se/fr/latestgo/Histoire_de_la_culture_des_plantes_sucri\% $C_{3} \%$ A8res.

main reason for adopting digital media: to give access to collections, first to the museum staff and later to all potential online users. However, the approach to do this has changed over time in ways that reflect the influence of the institutional make up, of policy and of the market (the outside user). This paper draws from a five-year research project aiming to document the process of adopting digital media that culminated in a dissertation entitled 'A History of Digitization: Dutch Museums.' 9 This paper hopes to contribute to the body of work on museum and media theory by proposing a new application of a theoretical framework, namely by using the social construction of technology theory (SCOTS) developed by Wiebe Bijker and Trevor Pinch. The analysis of empirical data from a media historic perspective covering a fiftyyear period represents one novel approach to understanding the role of media in defining our future digital heritage landscape.

The rest of the paper is organized as followed: section two presents the role of the user in the adoption and adaptation of technology based on scots. Section three reviews the major changes while adopting technology identified in Dutch museums as they increasingly publish collections online. Section four closes with a discussion and conclusions.

\section{The Social Construction of Technological Systems}

In the post-war era, research on technology emerged as a way to understand production systems within organizations that sought efficiency. ${ }^{\text {IO }}$ A technological determinist body of literature emerged which saw technology as the key determinant for social behaviour. In the I970s, a number of researchers realized that different users responded differently to computers. Scientists then began to approach technology from a social perspective, as they believed that the role of the user had as much impact on the outcome as did the technology. They further identified a number of additional determinants and their relationships, and 
developed the contingency theory. In the I980s, a new perspective emerged which took technology as a concrete object of study.

Two important variants emerged. The Actor Network Theory (ANT) established its focus on the role of non-human agents (machines or natural forces) to explain the development of technology while the Social Construction of Technological Systems (scots) looked at the processes found in social and group dynamics that shaped technological change. According to sCOTs theory, it is through a social understanding of a technology that users choose to adopt it or not, based on the perceived problem that this technology is meant to solve. ${ }^{\text {II }}$ As example they use is the bicycle: as the technology was made available to several user groups, including the elderly, sport cyclists and women, they each adopted the new technology to solve a perceived problem. In the process, each user group demand particular changes to the bicycle: women required special dress solutions, the elderly demanded safety while racers wanted speed. As technology developed, many bicycle designs were created and brought to the market including the Penny Farthing (1878), the Kangaroo bicycle (1878), the Facile bicycle (I874) and the Lawson bicyclette (I879). "Because social groups define the problems of technological development, there is flexibility in the way things are designed, not one best way." ${ }^{22}$

Because each group can have its own specific problem, technology can develop by responding to different user needs at the same time and therefore development follows not a linear path but a dynamic course of trial and error. Current technology is not a conscious, linear, rational collection of decisions that result in the best solution. Instead, there is flexibility in the social interpretation of technology, just as there is flexibility in the way artefacts are designed. Research, according to the scots theory, should acknowledge this and respond accordingly by analysing technological development through a multidirectional model to map both successes and failures. In doing so, the process of negotiation between the user and the developing technology emerges. The success of a technology's ability to solve a problem, or its failure, depends on the user group's belief of what the problem is and to what degree this has been solved by the new artefact. Clearly, there can be different problems and multiple solutions at the same time. It is in moments of controversy regarding the social perceptions of a technology's ability to solve a problem (or not) that the multidirectionality of technological development is brought to light: user groups and technology are entangled together. ${ }^{13}$ Back to the bicycle example: the air tire was the solution to the vibration problem, it also facilitated speed, yet it was not only ugly but unsafe (due to side-slipping). The result of a new technology either solved one or another problem, or none at all, depending on the user group's perception and interpretation of what the bicycle was meant to be.

Why do some solutions 'die' while others 'survive'? Technology develops in response to the user's needs, creating multiple solutions to eventually solve a problem. This brings a closure, or stabilization, of a debate. In fact, it is not necessarily that the new artefact resolves all user problems because it is social groups who define problems. That is, social groups can create or give closure to problems by reinterpreting them or by believing they are solved. The social dynamics of these processes are well understood by advertisements. In the first case, a new problem can arise whereby the old problem is solved by default. In the second case, the solution 
may be reached temporarily or partially, which may be a sufficient change. ${ }^{\mathrm{I}}{ }^{4}$ Again, using the bicycle example, reinterpretation took place when the air tire switched the attention from the safety and comfort problem, to the how-to-go-as-fast-as-possible problem, solving the safety discussion. Similarly, an advertisement for a slightly smaller front wheel claimed to make bikes almost absolutely safe, masking the problem of safety and making users believe the new model solved the old problem.

As it can be expected, closures are not fixed. Eventually, the social use of technology will be confronted by new problems, new technologies and new interpretations making this a longterm cyclical process of closures and re-openings.

\section{The Dutch museum path to online access to collections}

The culture of the Internet supports the belief that content is to be freely accessible, in all formats, to solve all information needs of all users at all times. ${ }^{15}$ Museums are slowly participating in the online information network by positioning their collections at their websites or in portals such as Wikimedia or the European digital library Europeana. However, there are fundamental differences in the approaches to collection publication found online. As example, we can see the print entitled Europa in een bibliotheek, currently part of the Rijksmuseum collection in Amsterdam, published on the museum's website (illustration 3) and on the Europeana portal (illustration 4). The first example shows a close up of a print, which centres on the main figure of Europa inside the library. The publication is visually oriented, with minimal information at the first click, though additional information is available by scrolling down and clicking further.

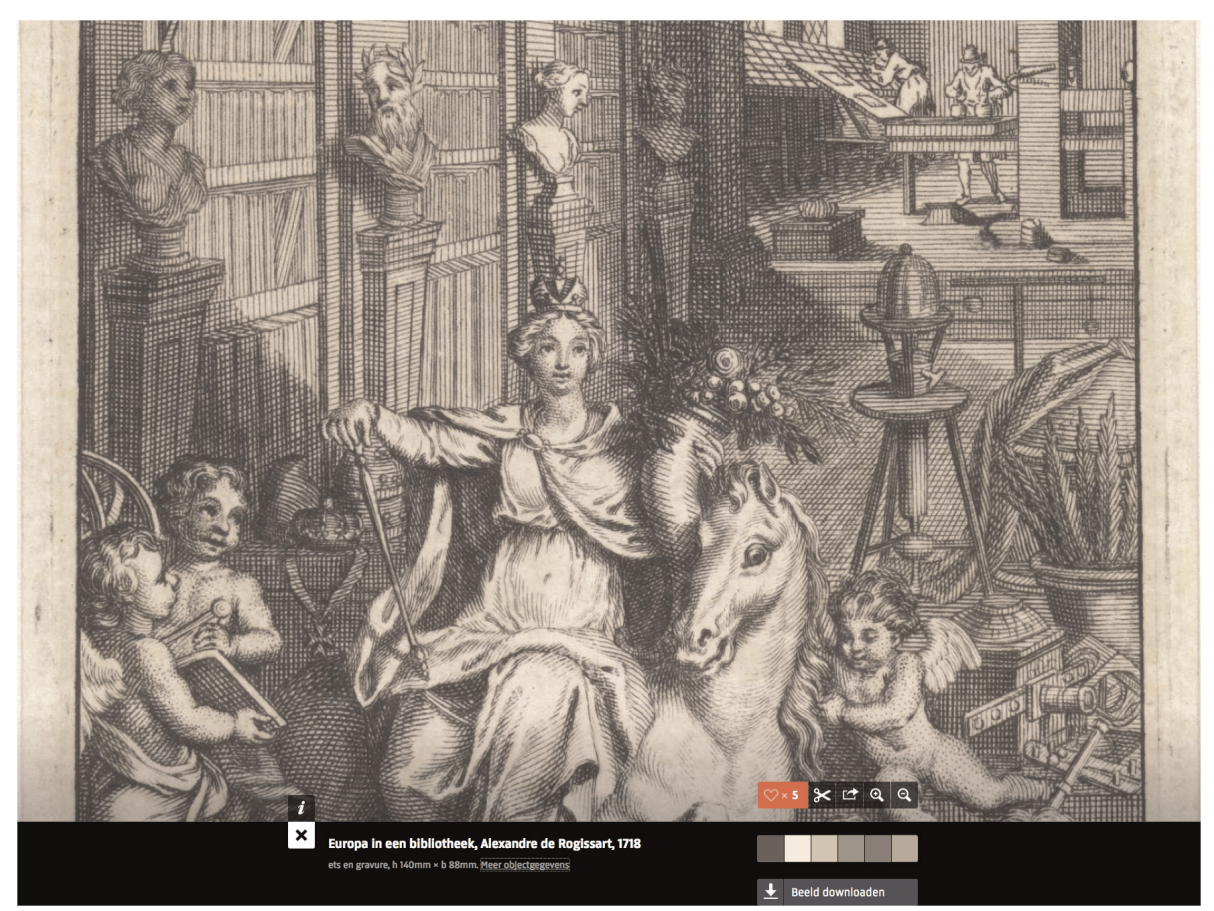

Ill. 3. Europa in a library, Rijksmuseum website.

Source: https://www.rijksmuseum.nl/nl/search/objecten?q=1\%27europe+savante\&p=I\&ps=I2\&ii=o\#/RP-P-OB-5I.507,०. 
The second example, on the contrary, shows the complete print but only as a thumbnail on the top left of the page. There are buttons allowing the magnification of the image and there is a link to visit the print at the contributing institution's website. However, the approach of the Europeana portal is clearly different: the print is published in a text-based semantic information environment, filled with hyperlinks and tools to share, reuse, translate and further navigate. In other words, the content is published in a standardized format that facilitates the finding, sharing and combining of online content. ${ }^{16}$

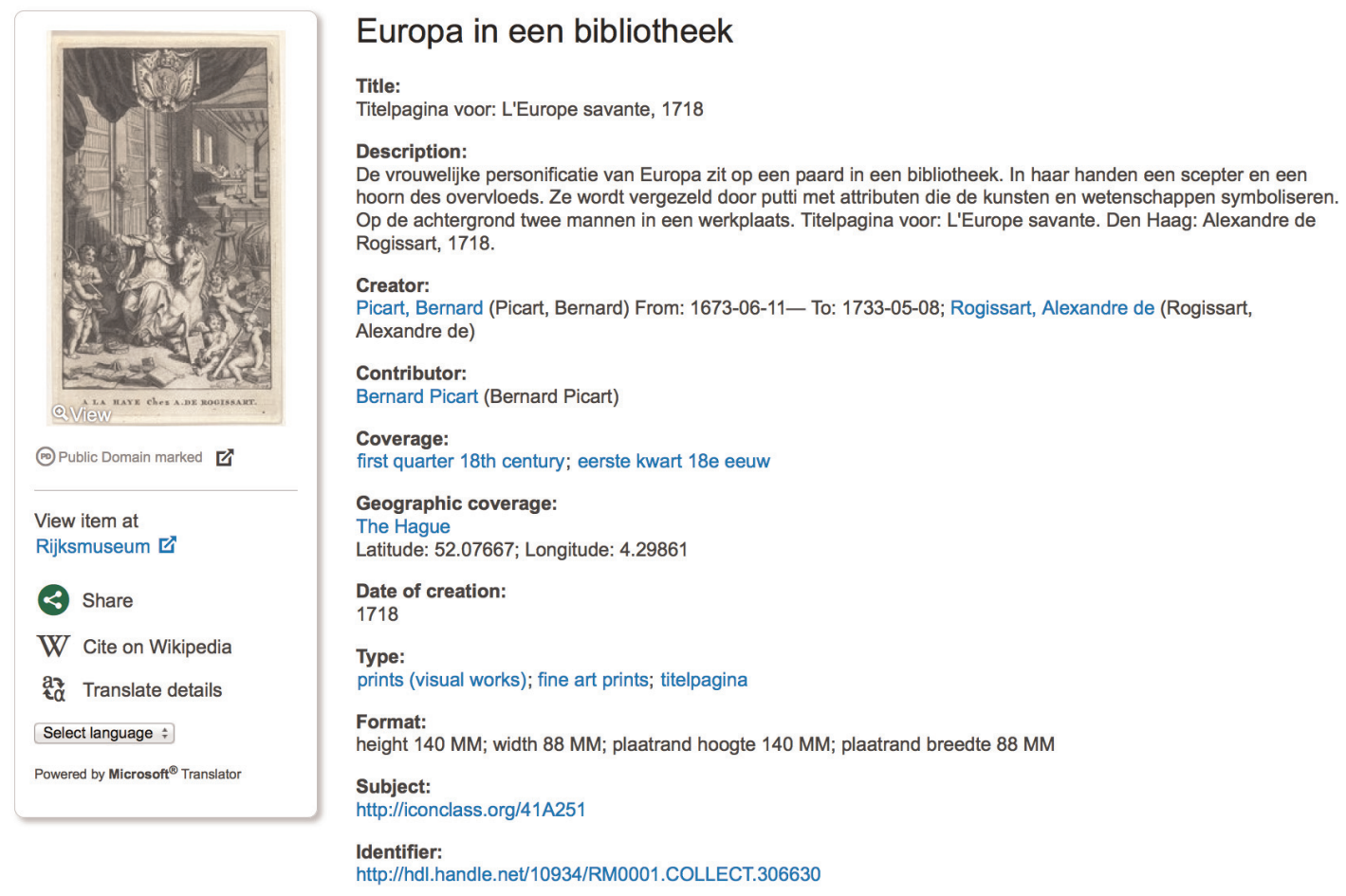

Ill. 4. Europa in a library, Europeana website.

Source: http://europeana.eu/portal/record/90402/RP_P_OB_51_507.html

The two examples exemplify a fundamentally different approach to the online publication of collections, whose origins lie in the unnecessary disconnection of user groups, as this section will attempt to document, that has been magnified by the adoption of digital technology. That is, museums are about the representation of information through collection illustration as much as their documentation. This is because of the museum's serving different users' needs.

Documentation in museums has a long history. Many information systems have been developed using a manual, paper-based technology in the form of inventory logs, as the one depicted in illustration 5, or using object cards, reflecting the influence of library systems as their technology expanded across sectors. Generally, museums documented the basic information about their acquisitions including inventory number, date, origin, significance and value. Those in charge of tracking objects developed information systems to serve their institutional needs based on collection type and size, staff size and knowledge about information systems. In this way, every museum had a system to manage collections, some 
being specialized, extensive, detailed or personalized. The Amsterdam Historisch Museum developed one extensive information system in the I950s. It included a registration card, a photo card, a reference card, an administration card, an inventory book and multiple elaborate index systems (including iconographical and topographical index cards) that allowed multiple access points to the collection. ${ }^{17}$ Hand-made information systems bare a strong signature of the maker, sometimes including drawings or excluding apparently redundant information (i.e. name of the registrar, which can be identified by the handwriting).

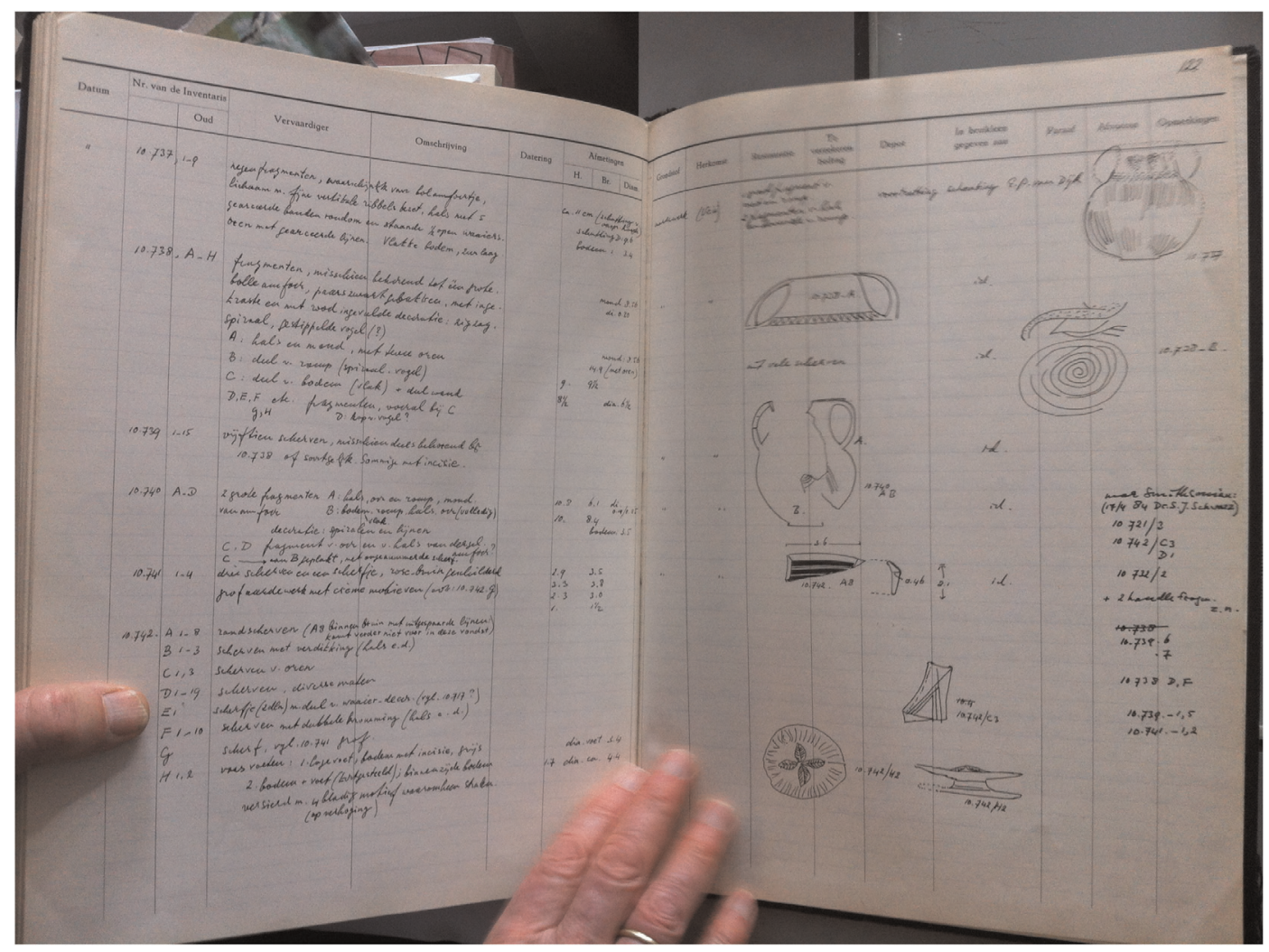

Ill. 5. Acquisitions logbook, Allard Pierson Museum.

Museum staff was the main user of collection information and was the initial driving force behind the first experiments in the automation of collections using the punch card (see illustration 6). Until about the I980s, the new digital technology was made up largely of paper information systems (punch cards or standard registration cards) used to prepare data migration into digital systems. The adoption of the new technology was driven by enthusiastic individuals who saw a future in the promise of remote access to collection information. ${ }^{\text {I } 8}$

As museums explored the use of mainframe computers to automate collection information, they began to realize the importance of standardization when naming objects: national thesauri projects emerged to unify museum registration by type of collection (i.e. ethnographic, natural history, art). Awareness of the importance of standardization led to the development of Registration Object Cards, designed to document art and natural history collections. Adoption of computers and development of standards was an international trend, though very much based on local knowledge as efforts responded to local user information needs. 


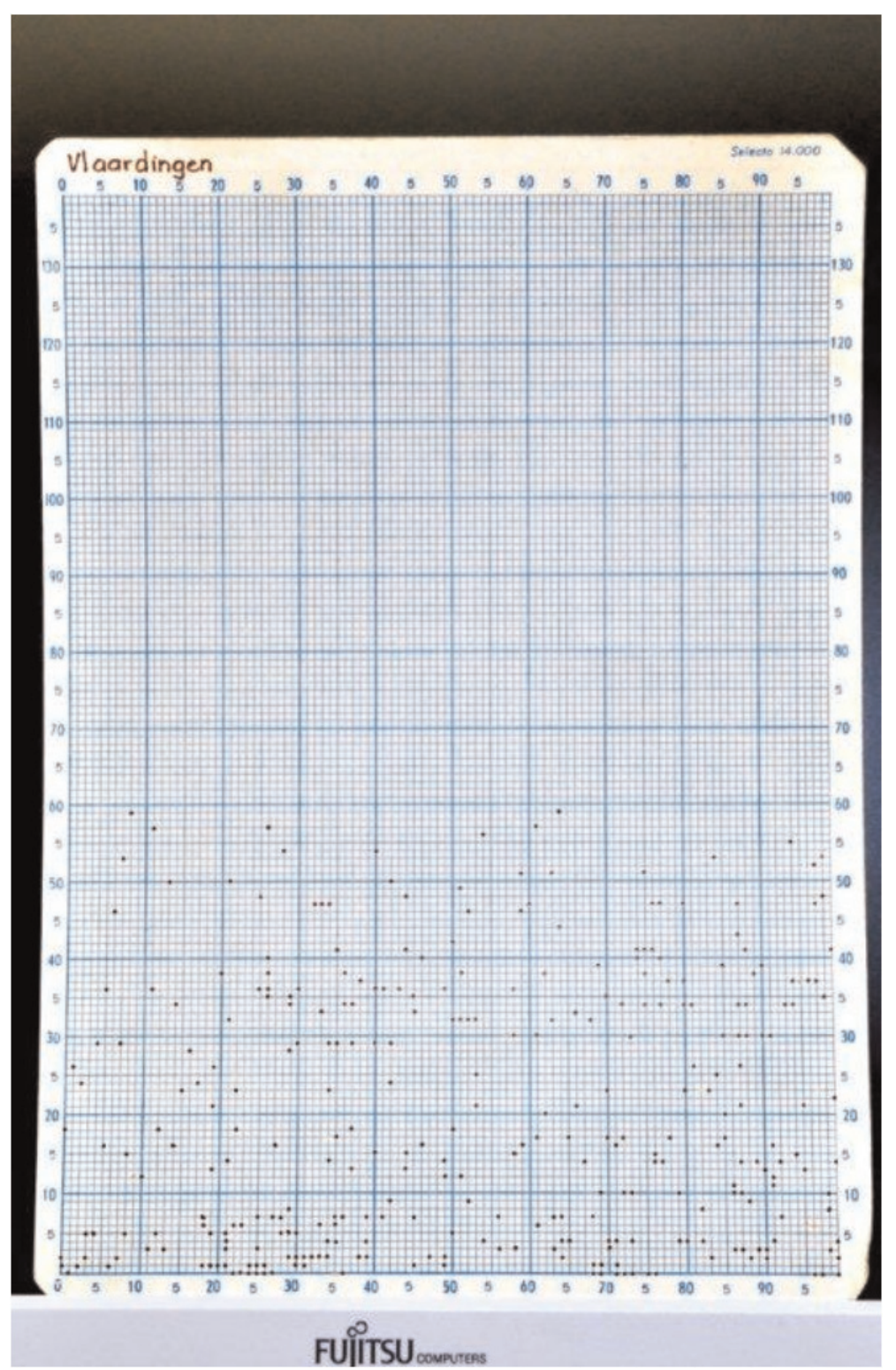

Ill. 6. Punch card of bibliographic records containing "Vlaardingen", Visserijmuseum.

Computers were not widely known or understood, were extremely expensive and were generally associated with industry. Adoption was slow: in 1988 there were about 56 museums with a computer and by 1990 there were more than 200. ${ }^{\text {I9 }}$ Systems were designed for textbased collection information management, generally meant for internal use and to serve as tools for daily work (see illustration 7). These systems, building up from the standardization work in the previous decades, slowly enabled the inclusion of images to identify objects, which was particularly useful for objects with no title.

In the I990s, the Ministry of Culture began a national inventory project called the Delta Plan for the Preservation of Collections, to identify the location, state and value of all national collections. This was the start of a policy to privatize museums. Resources were made available to acquire computers, to develop software and to automate collection registration. The project lasted more than ten years and most collections were accounted for, though not all at object level. Some large collections, such as the print collection at the Rijksmuseum in Amsterdam, 


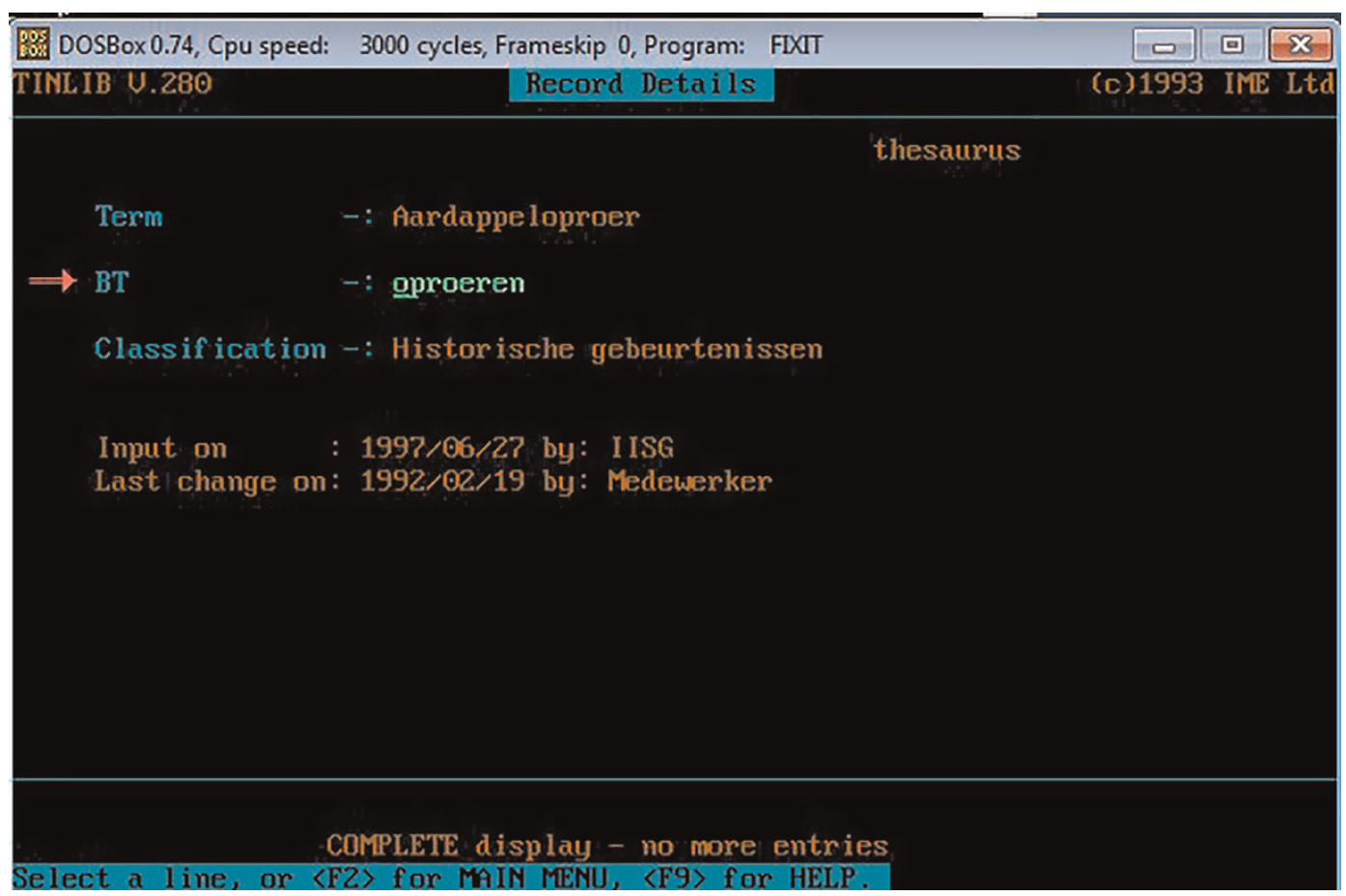

Ill. 7. Screen shot of collection registration software TINman, record details page.

are still registered in the so-called archive level, which includes the name of the box (or folder containing the prints) and a general description of the content, lacking object information. By 2009 , about $15 \%$ of the print collection was registered at object level. ${ }^{20}$ In 2013 , three quarters of all Dutch museum collections have been registered at object level in a digital information system. $^{21}$

Digital information systems developed in response to the museum user needs to allow free-text search, detailed thesauri links, storage of multi-media and increasingly complex registration fields. With the new systems, initial three-field computerized data sets resulted insufficient. The role of the researcher and registrar thus continue to be essential as there will always be additional information and perspectives to highlight about each object. As curator Jan Piet Filedt Kok from the Rijksmuseum said: objects are valued in so far as there is information available about them. ${ }^{22}$

Parallel to the development of systems to support internal work processes, a number of digital image-based products were being developed (see illustration 8) to present collections offline. These were generally digital translations of exhibition catalogues, though some museums ventured to develop games and virtual exhibitions as early as the I990s.

Publishing collection information was often seen as being independent from the information system used for object management. This conceptual disconnect led to a number of projects that provided access to collections but that soon became obsolete. One such example was the system was called ARIA, for Amsterdam Rijksmuseum InterActive documentation centre. Data maintenance for the database information system was not transferred to the online platform causing a problematic situation. ${ }^{23}$ No overview has been made of the number of websites launched with collection information that is no longer maintained or accessible. It is not clear if museums interpreted online publications as ephemeral publications or as 


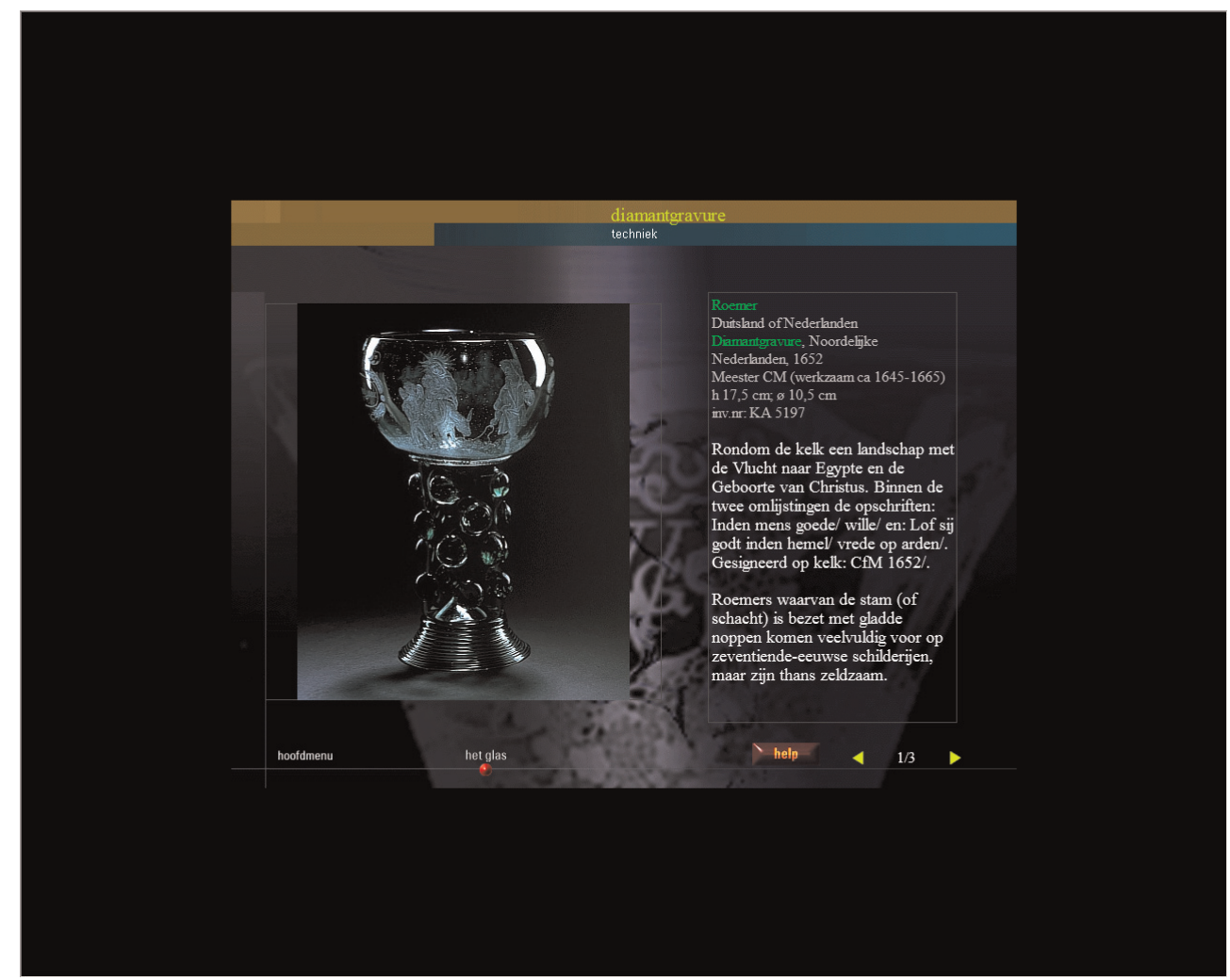

Ill. 8. Screenshot of a diamond engraving object, object view, part of the Amsterdam Historisch Museum Glass Collection digital catalogue.

translations of printed catalogues. Either way, museums interpreted online publication as generally for marketing and to support physical visits, as digital brochures and not as a place to showcase collection information.

Alternatively, the Tropenmuseum approached online publication as an opportunity to give access to its collection information system. In 2002, two versions of the collection were launched online: one was made up of selected objects in the collection that were registered and had an image, meant for the general public, while a second version gave access to the entire information system, meant for research and requiring a password. ${ }^{24}$

Increasingly, Dutch museums are striving to give access to their entire collections, made up of all holdings in the museum and the library systems. The Amsterdam Museum, the Rijksmuseum Amsterdam and the Netherlands Institute for Sound and Image have published (part of) their collections as open data in the 20Ios, setting an important trend in national practice. In fact, a new initiative was started to support the online publication of open data from the cultural sector called Open Cultuurdata (http://www.opencultuurdata.nl/). However, of all the objects held in museums, it is estimated that only about a quarter are available online for the general public. ${ }^{25}$ It is not clear to what extent the limited publication of collection information is due to a lack of resources to digitize and to obtain intellectual property rights or due to an interpretation of digital networked technology that excludes full disclosure of collections. Still, showcasing a selection of objects remains an important use of digital technology in museums.

As museum collections are found online, sometimes digitized and posted by the public, as in the case of the video gone viral from the Amsterdam City Archive, ${ }^{26}$ new forms of communication and interaction with the public have emerged. Initially, the user of the digitized 
collection information was largely made up of data professionals (or registrars) working in museums. These users developed and learnt a language for retrieving information, generally made up of administrative data. By the 2oros, museums explored with the creation and use of knowledge around the collection by enabling and stimulating thought and reflection among an increasingly broader user base. Museums were to expand beyond the walls through the digital network and the public was to become a co-creator of collection information. The inclusive notion of the user became key to achieve engagement and to support creation of relevant content. Increasingly, museums supported the creation of information systems that included alternative sources of information (made by users) and allowed collection information to flow in alternative information systems (e.g. Wikimedia).

\section{Discussion}

Museums have followed different processes to publish collections online and future online availability of content seems to be determined by the institution's interpretation of the media. Adoption of digital technologies in museums was driven by the wish to increase access to collections by facilitating entry points. That is, when paper cards allowed access only through inventory number or alphabetically by author, any other question resulted in complications. Curators wanting to see all the objects originating from a particular geographic location and made in a ten-year period would require an intensive search in a manual system, compared to the necessary two filter data clicks needed in a digital one. Keywords facilitated collection findability as well as thesauri and standardization of information organization. Eventually, museums adopted PCs to solve a new problem: remote access to information. Though this vision was present in particular individuals before the 2000s, it was not until the Internet was broadly adopted that museums realized the possibilities at hand. In fact, the old problem gained a new dimension.

The problem, facilitating access locally and remotely to collection information, has not fully been resolved for two important reasons. First, the user pool has expanded to include all potentially interested individuals who have voiced a variety of information needs. Second, technology has developed to allow what appears to be an endless level of detail and contextualization to document each object as well as new viewing interfaces, bringing a whole new dimension to the meaning of access. One problem did find closure: museums adopted PCS to decrease redundancy brought by the nature of manual systems which required the retyping of information in order to increase access points.

A certain controversy can be identified in the I990s around the reason to digitize. A new group redefined the problem: government officials in charge of developing new policies for resource allocation interpreted computers as tools to increase efficiency in collection management. Their perspective partially minimized the goal of increasing access, ever so slightly. Policy-makers continue to struggle with lack of data about collections particularly when estimating the amount of materials requiring conversion and funds needed to do so, as exemplified by the European statistical exercise aiming at documenting the size, cost and use of digital heritage called ENUMERATE. Nevertheless, the great efforts to migrate data from manual systems to digital ones was financed by the need to allocate resources based on number of 
objects and therefore produced inadequate datasets for collection discovery. When the government believed the problem of efficiency was solved, the inventory project was ended, bringing closure to the problem. Museums have returned to their driving goal, to facilitate access to collections, as they continue the process of adopting a digital work form. The example of Wikipedia at the beginning of this article reflects one approach to this goal.

Another controversy can be identified around the role of the user. The approach to the digital publication of collections can serve as example. The first offline catalogues and online displays were designed by museum staff for outside users (in what is called a supply driven demand). The user needs at the time were not documented, making it hard to know if the museum took the user information needs into consideration and to determine if the problem ever came to a closure. User participation was not what it is now. Current users expect to share, reuse, translate and further navigate through the online information network in any device of choice. The response of museum institutions has slowly changed, driven in part by the louder voice of online users. Online surveys have been increasingly conducted to improve findability, usability and general satisfaction as museums explore new ways to increase engagement with collection information. That is, the problem of developing online catalogues found closure when a new problem was defined: accessibility of collections through engagement. Publication of collections is one example that points to a fundamental change in the relationship between the museum institution and its public.

A final controversy can be found around the concept of the object. To discuss this, different approaches to represent collections visually will serve as examples. Technical development and costs can be said to be the main reasons to limit visualization of objects. Few museums currently display 3D versions of their objects or provide gigapixel images (billion pixel images first used by the Google Art Project). However, manipulating objects or viewing objects at extremely high resolution were not problems identified by museums. Initial images were meant to facilitate identification of objects, for instance, those lacking a title and to complement the text-based information systems. The images used in digital catalogues were literal translations to a new medium and those published online were generally meant to illustrate the institution in a sort of advertisement. The problems have, instead, found closure as new problems (possibilities actually) are permitted by high quality visuals. One example is the 3D visualization project of fragile objects that took place in 2008 at Museumgauda. ${ }^{27}$ Broad access was the driving goal behind the first 3D experiments in museums, which were only defined as problems in the 2000s, long after digital technology was applied to solve the visualization of architecture (in the I970s with CAD, the Computer Aided Design software able to make 2D and 3D models). New forms of visualization have been questioned on their ability to supplement or complement physical objects. This has led to an authenticity problem, slowly brought to closure as objects are redefined with digital qualities and as new sustainability problems emerge.

Since the start, digital technology was meant to solve the problem of access to collections, locally and remotely, by internal and by external users, textually and increasingly visually. As technology continues to develop in response to the institutional needs, as well as to public 
needs, new levels of object documentation and visualization will emerge to expand our notion of collection access.

\section{Conclusions}

The history of digitization of Dutch museums can be analysed using the scots theory framework. As museums interpreted digital technology to be of use, they have encountered sets of problems and solutions. A recurring problem to be solved digitally has been the ability to facilitate access to collections. The process of adopting and adapting to the new medium has led to fundamental changes in the institution. In this paper, three main controversies have been identified: the reason to digitize, the definition of the object and the relation with the public. Following the nature of technological development, it is expected that new problems will emerge as users redefine or bring closure to old problems.

\section{Notes}

I. R. Rogers, Digital Methods, Cambridge, The miт Press, 2013; S. Niederer and J. van Dijck, "Wisdom of the crowd or technicity of content? Wikipedia as a sociotechnical system' in: New Media \& Society, Vol. I2, No. 8, p. I368-1387; J. Rothschild, Machina ex Dea: Feminist Perspectives on Technology, New York, Pergamon Press, I983.

2. E. Yakel, 'Inviting the user into the virtual archives' in: OCLC Systems \& Services: International digital library perspectives, 2006, vol. 22, Issues 3, p. I59-I63; J. Oomen, and L. Aroyo, 'Crowdsourcing in the cultural heritage domain: opportunities and challenges' in: Proceedings of the $5^{\text {th }}$ International Conference on Communities and Technologies, 20II, New York, ACM, p. I38-I49.

3. http://outreach.wikimedia.org/wiki/GLAM/Case_studies\#Tropenmuseum.

4. For a list of projects and initiatives of Wikipedians in Residence see http://outreach.wikimedia.org/wiki/ Wikipedian_in_Residence.

5. Project coordinators Olaf Janssen (National Library) and Tim de Haan (National Archive) presented a retrospect (http://www.slideshare.net/OlafJanssenNL/terugblik-wikipedianinresidence-en-mogelijkheden-met-wikipedia-in-detoekomst). See also http://www.kb.nl/nieuws/nieuwsarchief-20I3/wikipedian-in-residence-gestart-bij-kb-en-nationaal-archief.-

6. ICT gebruik van personen naar persoonskenmerken, CBS, StatLine.

7. Cameron and Robinson, 'Digital Knowledgescapes: Theoretical, Practical and Usage Issues Facing Museum Collections Databases in a Digital Epoch' in: Cameron and Kenderdine (eds.), Theorizing Digital Cultural Heritage: A Critical Discourse, Cambridge, The MIT Press, 2007, p. 165-192.

8. P. Marty 'Information Representation' in: Marty and Burton Jones (eds.), Museum Informatics: People, Information and Technology in Museums, London, Routledge, 2007, p. 29-34.

9. Data was collected in the period between 2009 and 2013 to include a literature review, sixty-eight interviews with experts in the field, and six case studies selected: Allard Pierson Museum, Amsterdam Museum, Naturalis Biodiversity Center, Maritime Museum Rotterdam, Rijksmuseum Amsterdam, and the Tropenmuseum. For the final report of the dissertation see T. Navarrete A History of Digitization: Dutch Museums, Amsterdam, 20I4, available online at http://catalogus.boekman.nl/extern/detail.aspx?parentpriref=.

Iо. Woodward; Perrow I967.

II. W. Bijker, et. al. The Social Construction of Technological Systems. New Directions in the Sociology and History of Technology, Cambridge, The MIT Press, 2012.

I2. Idem, p. 6, 20-39.

I3. Ibidem, p. 7, 35 .

I4. Isbidem, p. 7, 36-39.

I5. Farchy. Yakel.

I6. See the entry about the Semantic Web at http://en.wikipedia.org/wiki/Semantic_Web.

I7. G. Reichwein, Van collectieregistratie naar publieksinformatie, AHM, Amsterdam, I998, p. 5-8. 
I8. Navarrete, A History of Museums, p. 8-I4.

I9. J. van de Voort, 'Doorbraak bij Museale Collectie Automatisering' in: Museumvisie. Jr. I5, No. 2, June I99I, p. 45-47.

20. Year Plan Collections Department, 2008, internal document, Amsterdam, Rijksmuseum.

2I. ENUMERATE data set 20I3.

22. Personal interview, 2 April 20I2, Amsterdam.

23. Jaarverslag 1995, Rijksmuseum, Amsterdam, I996:57; Van der Heiden, I998:9-10; Dreu and Kiers, I998.

24. M. Beumer, Capturing Museum Knowledge. A twenty year evolution in digitally recording the Tropenmuseum collection. Bulletin 386. KIT Publishers, Amsterdam, 2008.

25. ENUMERATE dataset 2012.

26. The video 'De groei van de Grachtengordel' was made by the Amsterdam Archive for the 2013 exhibition 'Booming Amsterdam' to be seen onsite. The video was filmed by a visitor of the exhibition who shared it on YouTube. The video went viral and received much attention, forcing the Amsterdam Archive to reconsider online publication policy to eventually result in an official publication of the video at the institutional channel (available at http://youtu.be/IvsHvfs3GiM).

27. AD.nl., Aanraken mag in museumgouda, 8 December 2008. DEN project bank: http://www.den.nl/project/250/ Hebbes!-Het-digitaliseringsproject-van-museumgoudA. 
